\title{
Development of Laboratory Work Instruction for Junior High School: Borax Content Identification Using Natural Indicators
}

\author{
Nanang Rahman ${ }^{1}$, Agus Abhi Purwoko², Muntari ${ }^{3}$ \\ ${ }^{1}$ University of Muhammadiyah Mataram, Teachers Training and Education Department, \\ J1. KH. Ahmad Dahlan, Pagesangan, Mataram City, Indonesia \\ ${ }^{2}$ University of Mataram, Teachers Training and Education Department \\ J1. Majapahit No.62, Gomong, Mataram City, Indonesia \\ ${ }^{3}$ University of Mataram, Teachers Training and Education Department, \\ J1. Majapahit No.62, Gomong, Mataram City, Indonesia
}

\begin{abstract}
:
The main goal of this study is to develop a laboratory work instruction for junior high school, in particular in identification of non food additives, such as borax, in daily foodstuff. The method of development is referred to a four-step procedure by Borg and Galls. There are 94 samples of extract of leafs and flowers of various tropical plants that have been examined for identification of borax. Of these samples it is found that there are 4 flower extracts that indicate sensitivity to the borax content, namely Ruellia Simplex, Curcuma Longa, Plumeria Ruba, and Portulaca Grandiflora. In later stage of development the laboratory instruction were validated by academic experts and school teachers. The results of validation indicate that the guideline is suitable to be implement in laboratory works at junior high school.
\end{abstract}

Keywords: laboratory work, borax test, natural indicator

\section{Introduction}

Indonesia is currently still using borax for food. Borax is often used as an additional snack ingredient. One report shows that the borax concentration up to $136 \mathrm{~g} / \mathrm{kg}$ of wet noodle, a foodstuff that is commonly sold in traditional market, is found in Manado city Indonesia (Payu, 2016). Consuming foodstuff that contains a small amount of borax is not considered fatal, but the accumulation in body due to prolong consumption of contaminated foods will cause poisoning (Subiyakto, 1991).

Doses of 200-640 mg boric acid / $\mathrm{kg}$ have been reported to be lethal, but the number has not been fully verified (Fail et al., 1998). Another report states that the lowest deadly dose after accidental swallowing of boric acid by humans ranges from about 98 to $650 \mathrm{mg}$ boron/kg body weight (Teshima et al., 1992). Death has been reported when boron is administered intravenously at $0.5 \mathrm{mg}$ boron / $\mathrm{kg}$ body weight (EFSA, 2004).

There are several methods that have been used to test the presence of borax. Jacobi (1904) developed a method for testing boric acid with glycerine, then titrated with potassium hydroxide. There are three methods known for determining detailed boric acid in food, namely the titrimetric method using mannitol, and two colorimetric procedures using carminic acid or curcumin. Colorimetric procedures with the curcumin method is found to be the most reliable and therefore will be the method of choice for the determination of boric acid in food (Mizura et al 1991). Another method is fast quantitative analysis of boric acid by gas chromatography - mass spectrometry coupled with a simple and selective derivatization reaction using triethanolamine (Zeng et al 2009).

The methods for testing borax described above are expensive and they are less feasible for classroom instruction, in particular to be implemented for junior high school. Alternative methods should be developed using simple, low cost, and accessible procedures (Nanang, 2018). In science learning it is suggested that direct reflective methods should be used rather than indirectly for students to understand the true nature of science (Hakim et al 2016). Direct reflective methods can be done through laboratory activities. This study aims to develop a laboratory work instruction for borax tests that is simple and easy to use in classroom instruction for junior high 
school students. The mentioned method uses natural indicators extracted from plants that are found locally. The procedure can be carried out in a simple and fast way for the purpose of qualitative testing.

\section{Method}

\subsection{Types of Research}

The procedure used in this kind of research is procedural development where the steps are explained in a concrete and detailed manner. The development procedure carried out refers to the one developed by Borg \& Galls (1996). Borg and Gall found that the development research procedure basically consisted of two main objectives, namely developing products and validating the products so produced. The description of this development model is explained in Figure 1.

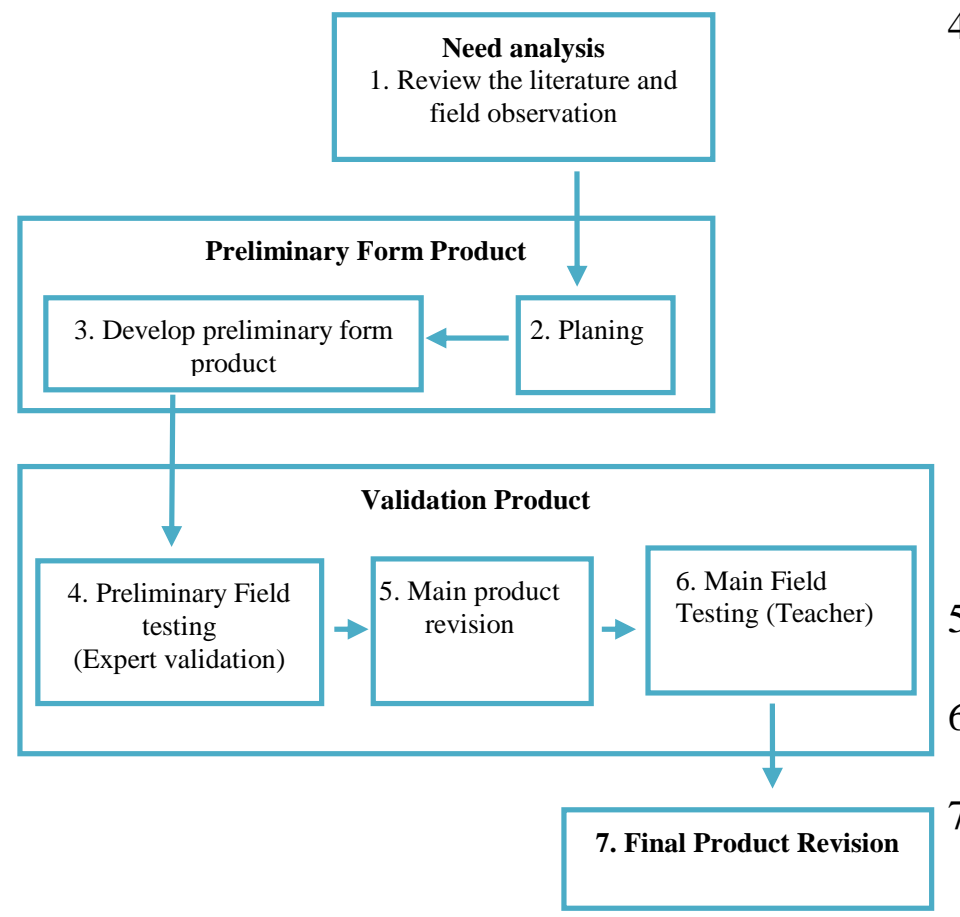

Figur 1: Development model

Details of the research procedures that have been carried out are as follows:

1. Library study activities by looking for literature relevant to research. Literature study was conducted to gather information, including studying the curriculum of integrated science subjects for junior high schools, reviewing the literature on the physical and chemical properties of borax

2. Field observations are carried out to see firsthand the state of the school environment, the potential of natural resources that can be used as a natural indicator. Field observations were carried out in West Nusa Tenggara Province.
3. Planning experiments on borax experiments with natural indicators. The draft laboratory work begins with a laboratory experiment using pure ingredients of borax compounds by using various types of natural materials that exist around the environment. At this stage also began to be designed simple materials for borax test indicators. Borax test practicum method with natural indicators as follows:

- Weigh 2 grams of natural indicator material, then cut into small pieces

- Grind natural indicators by using mortal

- Add $5 \mathrm{ml}$ of distilled water to the crushed indicator

- Separate filtrate with indicator residues

- Take 5 drops of the filtrate indicator then add 5 drops of borax solution

- Observe the color changes that occur

4. Develop preliminary product form using filter paper for a simple borax test tool. How to make indicator paper as follows:

- Cut the filter paper with a length of $7 \mathrm{~cm}$ and a width of $0.5 \mathrm{~cm}$

- Dip filter paper into the filtrate indicator

- Dry for 4 hours until indicator paper can be used

The step of the borax test practicum with natural indicators is then compiled in practical instructions that can be used by junior high school students.

5. Preliminary Field testing by validating by 1 chemist and 1 expert in science education

6. Play product revision based on input from expert validation

7. Playing Field Testing was conducted to 8 teachers in several schools in West Nusa Tenggara Province

\subsection{Data Collection}

The instrument used in this study is a questionnaire on the feasibility of products that have been developed. Preliminary Field testing is given a questionnaire to chemists and science education experts. Main field testing was given a questionnaire to 8 teachers in several schools in the province of West Nusa Tenggara. The questionnaire used contains 3 aspects of assessment: disability, graphics and practicality of use. Readability aspect: the instructions for using the borax test practicum book with natural indicators are easy to understand, the statements and sentences in the borax test instruction with natural indicators are easy to understand, the size and model of the letters used in the borax test 
instruction are clearly visible and easy to use. Graphical aspect: the drawings on the borax test instruction with natural indicators look attractive and clear, the cover in the borax instruction with natural indicators looks attractive. Practical aspects of use: the use of borax test practicum instructions with natural indicators is easy to use, the use of time is more effective when practicum with practical instructions borax test with natural indicators, the information provided in the borax practicum instructions with natural indicators makes practicum more active, creative, and fun, the procedures and work steps are presented in a clear and easy to use.

\subsection{Methods of Analysis Data}

Feasibility questionnaire for device products borax test is provided to experts and teachers. The data obtained from the questionnaire were changed to interval data. The questionnaire provided contains five choices to provide feedback about the practicum instruction products that have been developed, namely: very good (5), good (4), good enough (3), not good (2) and very poor (1). If the respondent gives a "very good" response then the statement item is given the number " 5 " and so does the other. The score obtained is then converted to a value on a scale of 5 with a table reference quoted from Saifuddin Azwar (2010), as follows:

Table 1. Conversion of Actual Scores to Five-Scale Values

\begin{tabular}{|c|c|c|}
\hline Score Interval & Value & Categori \\
\hline$X>x_{i}+1,5 \mathrm{SB}_{i}$ & P & Very good \\
\hline $\mathrm{x}_{\mathrm{i}}+0,5 \mathrm{SB}_{\mathrm{i}}<\mathrm{X} \leq \mathrm{x}_{\mathrm{i}}+1,5 \mathrm{SB}_{\mathrm{i}}$ & $\mathrm{B}$ & Good \\
\hline $\mathrm{x}_{\mathrm{i}}-0,5 \mathrm{SB}_{\mathrm{i}}<\mathrm{X} \leq \mathrm{x}_{\mathrm{i}}+0,5 \mathrm{SB}_{\mathrm{i}}$ & $\mathrm{C}$ & Good enough \\
\hline $\mathrm{x}_{\mathrm{i}}-1,5 \mathrm{SB}_{\mathrm{i}}<\mathrm{X} \leq \mathrm{x}_{\mathrm{i}}-0,5 \mathrm{SB}_{\mathrm{i}}$ & $\mathrm{D}$ & Not good \\
\hline $\mathrm{X} \leq \mathrm{x}_{\mathrm{i}}-1,5 \mathrm{SB}_{\mathrm{i}}$ & $\mathrm{E}$ & Very poor \\
\hline
\end{tabular}

Information:

$\mathrm{xi}=$ Average ideal score $=1 / 2$ (ideal maximum score + ideal minimum score)

$\mathrm{SBi}=$ Ideal standard deviation $=1 / 6$ (ideal maximum score - ideal minimum score)

$\mathrm{X}=$ Actual score (score achieved)

Ideal maximum score $=\Sigma$ item criterion $\mathrm{x}$ highest score

Ideal lowest score $\quad=\Sigma$ item criterion $\mathrm{x}$ lowest score

\section{Result and Discussion \\ 3.1 Result}

Early identification of plants that are used as a natural indicator to test borax is those that have a bright color, because the color of the borax solution is colorless (transparent). There are two parts of the plant that are used as the test material, namely leaves and flower crowns. Based on the field observations that had been carried out on plants in the West Nusa Tenggara Province, 94 leaf and flower crown samples were taken which were believed to have potential use as natural indicators for borax test.

Based on the results of the trial of $0.1 \mathrm{M}$ borax solution using various plant extracts that have been identified, 4 samples of extracts give positive reaction, namely: Ruella Simplex, Curcuma Longa, Plumeria Rubca, and Portulaca Grandiflora. The following are the results of the $0,1 \mathrm{M}$ borax trial with these 4 types of indicators.

Table 2. Test results of plant extracts

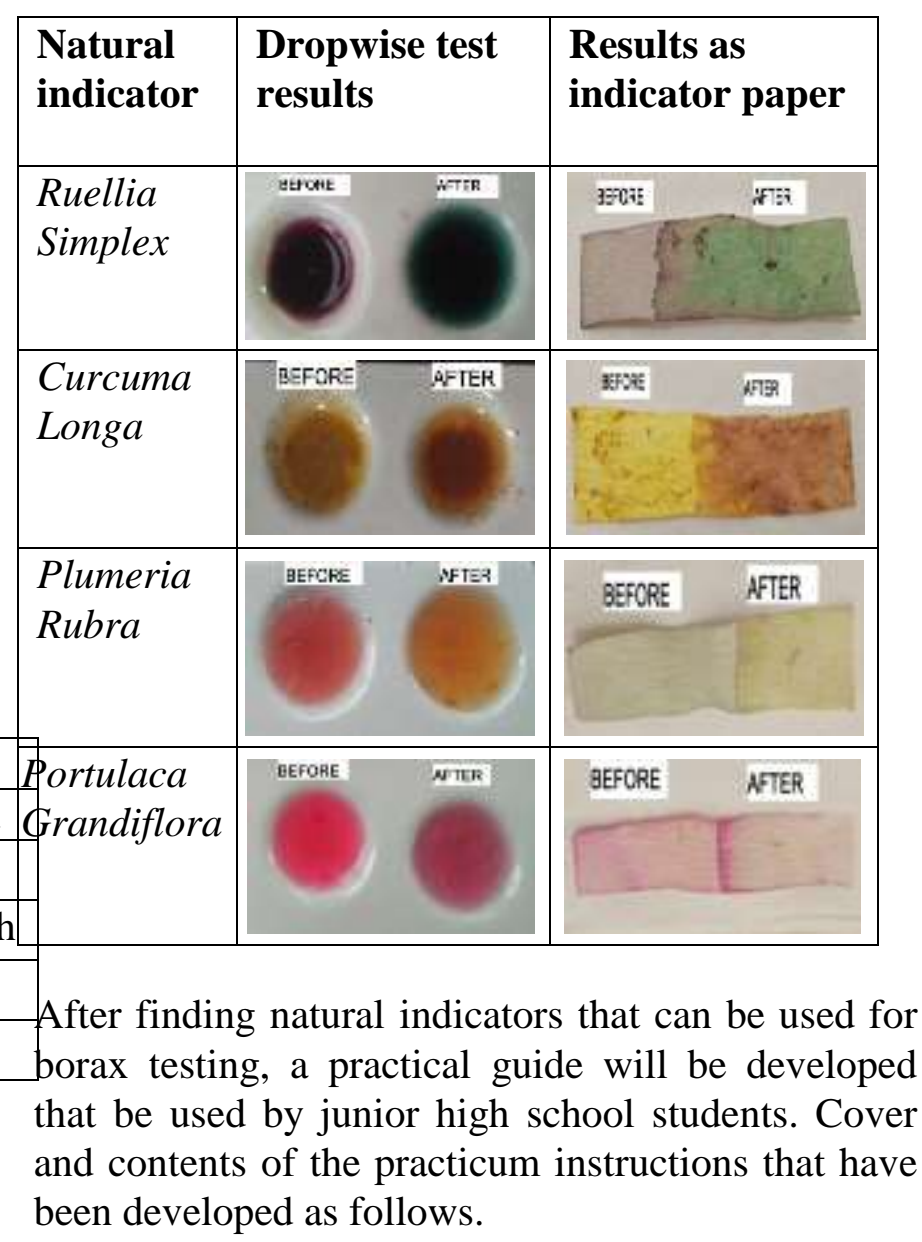
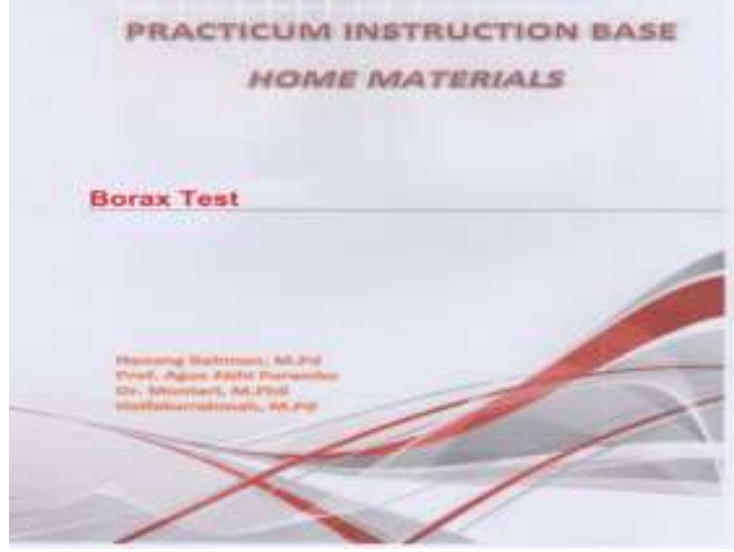


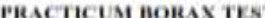

\section{Purpose}

- Undentand how to identify the presence of borax in food ?

- Form the character of responsibility, thorough and creative ?

\section{Theoretical foundation}

Borax is a chemical compound derived from heavy metal boron (B), Borax in an anti-neptie and germ killer. This material is widely used as an anti-fungal, wood preservative, and antineptic ingredient in coanetien (Svehla, G). Borie acid or boras (borie acid) is a dangerous preservative that is not permitted to be used an a mixture of food ingredients. Borax in a chemical compound with the formula $\mathrm{Na} 2 \mathrm{~B} 4 \mathrm{O} 7 \mathrm{H} 10 \mathrm{H} 2 \mathrm{O}$ in the form of white crystals, odorleas and atable at normal temperaturen and pressures. In water, borax changen to sodium hydroxide and boric acid (Shah, 2009).

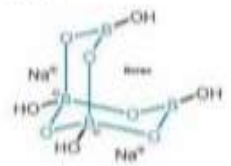

Boric acid (113803) is a drill compound known as bonax. In West Java it is also known as "bleng", in Central and Fast Java it is known as "pijer". Uned / addod to food / food ingredients an thickener of as preservative. From varioas studien that have been done, it is obtained data that this boric acid compound in uned in rice cake no that the texture becomen good and most are added to the process of making meatbails. The composition and shape of borie aeid contains 99.095 and 100\% $\mathrm{H} 3 \mathrm{BO}$. Has a molecular weight of 61.83 with $\mathrm{B}=17.50 \% ; \mathrm{H}=4.88 \%, \mathrm{O}=77.62 \%$ in the form of transparent crystalline powder or white granules that are colorlens and odorless and somewhat sweet (Cahyadi, 2008)

Borax characteristies inelude (Riandini, 2008)

a. The color is obviounly cleas

b. Luster like glass

c. Tranuparencien are transparent to translucent

d. Crystal system is monoelinic

Q. Splits are perfect in one dinetion

f. The coler of the white layer

8. Similar minerals are calcite, halite, hanksite, colemanite, ulexite and other boric acid salts

h. Other characteristica: an alkaline nweet taste
- Take 5 drops of indicator filtrate then add 5 drops of borax solution

- Observe the color changes that occur

b. Product development using filter paper for simple borax test tools. How to make paper indicators as follows:

- Cut filter paper with a length of $7 \mathrm{~cm}$ and width of $0.5 \mathrm{~cm}$

- Dip filter paper into the indicator filtrate

- Dry for 4 hours until the indicator paper can be used

- Dip the dried paper indicator with borax substance that has been put in the drip pallet

- Observe the color changes that occur after dipping in borax

Record the observations in the following table:

c. Test formalin on food ingredients

- Take 10 grams of food ingredients

- Puree food using mortal

- Enter $5 \mathrm{ml}$ of distilled water into food ingredients

- Take 5 drops of liquid food ingredients and put in a drop pallet

- Add indicator flower extract to liquid droplets of food ingredients

- Observe the change in color that occurs

\begin{tabular}{|c|c|c|c|}
\hline Natural indicator & Dropwise test results & Results as i & or paper \\
\hline Ruellia Simplex & & BEFORE & NFIER \\
\hline \multirow{2}{*}{ Curcuma Longa } & & stroes & NTEn \\
\hline & & BEFORE & AFTER \\
\hline 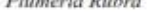 & & & $r$ \\
\hline Portulaca & & BEFORE & AFTER \\
\hline Grandiflora & & & \\
\hline
\end{tabular}

5. Evaluation

a. What plants can be used as natural indicators for borax testing?

b. Explain the criteria for selecting borax test material indicators?

c. What foods are often mixed with borax preservatives?

Figure 2. Cover dan conten laboratory work instruction

These boric acid compounds have the following chemical properties: melting distance of about $171^{\circ} \mathrm{C}$, dissolving in 18 parts cold water, 4 parts boiling water, 5 parts $85 \%$ glycerol and insoluble in ether. Solubility in water increases with the addition of hydrochloric acid, citric acid or tetrat acid. It evaporates easily by heating and losing one molecule of water at $100^{\circ} \mathrm{C}$ which slowly turns into metaboric acid (HBO2). Boric acid is a weak acid and alkaline salt is alkaline One gram of boric acid dissolves completely in 30 parts of water, producing a clear and colorless solution. Boric acid is not mixed with alkali carbonates and hydroxides (Cahyadi, 2008).

Borax is a soft crystalline powder containing boron, white, odorless, easily soluble in water, insoluble in alcohol and has a $\mathrm{pH}$ of about 9.5 . Borax is widely used in various non-food industries, especially in the hard industry, glass, wood preservatives, anti-septic wood, ceramics and cockroach controllers. Borax has long been used by the community for making rice rails. krupuk gendar, or puli crackers which traditionally in Java are called "Karak" or "Lempeng". Besides that borax is used for the food industry such as in the manufacture of wet noodles, rice cake, diamonds, meatballs even in making soy sauce.

3. Tools and materials

- Borax

- Aquades

- Filter paper

- Drop palette

- Drop pipette

- Mortal

- Glassware

- Cutter

- Hibiscus rosa

- Impatia balsamina flowers

- Red frangipani flowers

- Ruellia flower

- Plumeria flower

- Turmeric

- various types of food

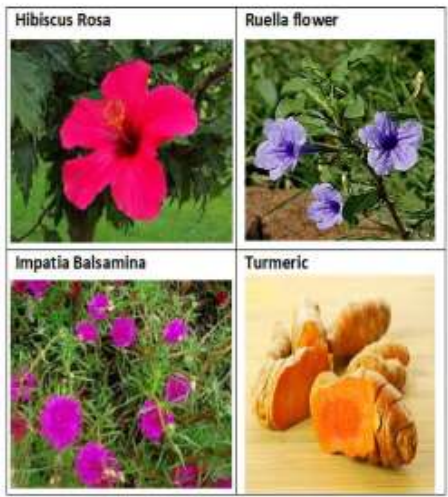

\section{Work instructions}

a. Borax drops test method with natural indicators as follows:

- Considering 2 grams of natural indicator material, then cut into small pieces

Grind natural indicators by using mortal

- Add $5 \mathrm{ml}$ of distilled water to the crushed indicator

-Separate the filtrate with indicator residue
The laboratory work instruction that have been developed are validated by experts and by request responses from teachers with questionnaire instruments. The following are the results of the expert validation questionnaire and teacher respons.

Table 3. Average results of expert validation and

\begin{tabular}{|l|c|c|c|}
\hline \multirow{2}{*}{$\begin{array}{c}\text { Assesment } \\
\text { aspect }\end{array}$} & \multicolumn{2}{|c|}{ Average rating } & \\
\cline { 2 - 4 } & Expert & Teacher & Average \\
\hline Readability & 12.50 & 13.20 & 12.85 \\
\hline Graphics & 7.50 & 7.60 & 7.55 \\
\hline Practicality & 23.00 & 23.50 & 23.25 \\
\hline
\end{tabular}

Based on the results of questionnaires that have been given to experts and teachers there are several inputs related to the practicum instructions that have been produced: (1)The image of the flower for the indicator is made clearer in color. Impatia balsamia flower images used in practicum manuals have low image resolution so that they are not clearly visible, (2) Larger image size to make it clear. The image displayed in the practicum manual is too small so that the type of flower is not clear enough to be used to test borax, (3) Filter paper as an indicator made smaller in size to make it easier to assessment of 8 teachers 
use. Initially the indicator paper from filter paper made was $1 \times 7 \mathrm{~cm}$ in size, but based on expert input suggested that the indicator paper size be reduced to $0.5 \times 5 \mathrm{~cm}$.

\subsection{Discussion}

In general, the color of flowers is caused by flavonoid and carotenoid pigments which can attract attention to help pollination. Flavonoids are the most common flower color pigment, and the dominant flavonoid pigments are anthocyanins. Anthocyanins are composed of anthocyanidin and sugar groups. They are the basis for most of the colors orange, pink, red, magenta, purple, blue, and blue-black. Common anthocyanidins are pelargonidin, cyanidin, peonidin, delphinidin, petunidin, and malvinidin, named after the genera from which they were first isolated. Most anthocyanins come from only the following three basic anthocyanidins: pelargonidin, cyanidin, and delphinidin (Davies, 2009).

The first natural indicator that is used as extract to identify borax is the ruellia simplex. The dyestuffs contained in ruellia simplex with purple color are anthocyanins (Freyre et al. 2015). Anthocyanins are a bioactive component of the flavonoid group found in flowers, leaves, yams, fruits and vegetables clinging to the $\mathrm{pH}$ of the environment in which they are located (Torskangerpoll \& Anderson, 2005; Burdulis et al, 2009). The structure of anthocyanins changes at $\mathrm{pH}$ 1, $\mathrm{pH} 4.5$ and $\mathrm{pH} 7$ (Lee et al. 2005). Changes in $\mathrm{pH}$ cause changes in the structure of the quinonoidalanidrobase $\mathrm{pH}$ 6.5-8 to cis-chalcone $\mathrm{pH}$ $>9$ (Marco et al. 2011). Borax solution which has a $\mathrm{pH}$ of around 9.5 when added drop wise to the extract of Ruellia simplex that shows purple color will experience a blue-green color change due to structural changes. Structural changes cause complement color changes that can be observed as an indicator to determine the presence of borax in a sample.

The second natural indicator used to identify borax is turmeric. Turmeric contains the main ingredient of yellow color known as curcumin (Anderson et al. 2005). Curcumin (1,7-Bis- (4-hydroxy3methoxyphenyl) -hepta-1,6-diene-3,5-dione) is an oil-soluble pigment, practically insoluble in water at acidic and neutral $\mathrm{pH}$, soluble in alkali and very vulnerable form of $\mathrm{pH}$ change (Gantait, 2011). However, in an aqueous system such as water, it can be understood that at alkaline $\mathrm{pH}$, the phenol group acid in curcumin donates hydrogen, forming phenolic ions which allow curcumin to dissolve in water. This form is not stable at neutral and alkaline $\mathrm{pH}$ for a longer period of time and easily degrades into compounds such as vanillin, ferulic acid, etc. This form is stable at a $\mathrm{pH}$ below 7.0 but with a decrease in $\mathrm{pH}$ value, shifting the dissociation equilibrium to a neutral form with very low water solubility (Wang et al, 1997). The curcumin obtained from turmeric can be used to decompose the borax bond into boric acid and bind it into a rosa color complex or commonly called the complex boron cyanocurcumin compound which is a red colored substance. The color change from yellow to reddish on turmeric can be used as a natural indicator material to detect the presence of borax in laboratory activities.

The third flower that can be used as a natural indicator material is the Plumeriarubra flower. Anthocyanins cause red to blue color in plants (Andersen \& Jordheim, 2005). The color changes that occur in plumeriarubra extract after being mixed with borax solution caused by changes in the structure of anthocyanins at $\mathrm{pH} 9.5$ as in the ruellia simplex flower.

The fourth indicator that can be used to identify borax is the flower of Portulaca Grandiflora which is an ordo of Caryophyllales plants. Betalain is a pigment that replaces anthocyanins in most families of the Caryophyllales plant ordo (Strack et al. 2003). In food processing, betalain is less commonly used than anthocyanins and carotenoids, although this water-soluble pigment, stable between $\mathrm{pH} 3$ and 7, is suitable for coloring low-acid foods (Leathers et al., 1992; Trejo et al., 1999; Akita et al., 2000). If Portulaca Grandiflora is mixed with borax solution which has a $\mathrm{pH}$ of 9.5, it will change the structure of the betalain so that the color will change from pink to red purple. This color change justifies the use of Portulaca Grandiflora to be a natural indicator to identify the presence of borax.

Using Table 1 as reference then the validation results and the teacher's response to the practicum instructions are then converted to a five scale. Following are the results of conversion scores for readability, graphs and practicality of use.

Table 4. The results of the conversion of scores to a scale of five

\begin{tabular}{|c|c|c|l|}
\hline Aspect & Interval & Value & Category \\
\hline Readability & $\mathrm{X}>12.0$ & $\mathrm{~A}$ & Very good \\
\cline { 2 - 4 } & $10.0<\mathrm{X} \leq 12.0$ & $\mathrm{~B}$ & Good \\
\cline { 2 - 4 } & $8.0<\mathrm{X} \leq 10.0$ & $\mathrm{C}$ & Fair \\
\cline { 2 - 4 } & $6.0<\mathrm{X} \leq 8.0$ & $\mathrm{D}$ & Poor \\
\cline { 2 - 4 } & $\mathrm{X} \leq 6.0$ & $\mathrm{E}$ & Very poor \\
\hline \multirow{5}{*}{ Graphics } & $\mathrm{X}>8.0$ & $\mathrm{~A}$ & Very good \\
\cline { 2 - 4 } & $6.6<\mathrm{X} \leq 8.0$ & $\mathrm{~B}$ & Good \\
\hline
\end{tabular}




\begin{tabular}{|l|c|c|l|}
\hline \multirow{4}{*}{} & $5.4<\mathrm{X} \leq 6.6$ & $\mathrm{C}$ & Fair \\
\cline { 2 - 4 } & $4.0<\mathrm{X} \leq 5.4$ & $\mathrm{D}$ & Poor \\
\cline { 2 - 4 } & $\mathrm{X} \leq 4.0$ & $\mathrm{E}$ & Very poor \\
\hline \multirow{4}{*}{$\begin{array}{l}\text { Practicality } \\
\text { of use }\end{array}$} & $\mathrm{X}>20.0$ & $\mathrm{~A}$ & Very good \\
\cline { 2 - 4 } & $16.6<\mathrm{X} \leq 20.0$ & $\mathrm{~B}$ & Good \\
\cline { 2 - 4 } & $13.3<\mathrm{X} \leq 16.6$ & $\mathrm{C}$ & Fair \\
\cline { 2 - 4 } & $10.0<\mathrm{X} \leq 13.3$ & $\mathrm{D}$ & Poor \\
\cline { 2 - 4 } & $\mathrm{X} \leq 10.0$ & $\mathrm{E}$ & Very poor \\
\hline
\end{tabular}

The results of expert validation and teacher assessment in table 3 compared with table 4, about the quality of borax test practice guidelines using indicators of Ruellia Simplex, Curcuma Longa, Plumeria Rubra, and Portulaca Grandiflora. Conclusion of the results of the assessment of practicum instructions as follows.

Table 5. Conclusions on the results of assessment of practicum instructions

\begin{tabular}{|l|c|c|c|}
\hline \multicolumn{1}{|c|}{$\begin{array}{c}\text { Assesment } \\
\text { aspect }\end{array}$} & \multicolumn{3}{|c|}{ Average rating } \\
\cline { 2 - 4 } & $\begin{array}{l}\text { Average } \\
\text { value }\end{array}$ & Interval & Category \\
\hline Readability & 12.85 & $\mathrm{X}>12.0$ & $\begin{array}{c}\text { Very } \\
\text { good }\end{array}$ \\
\hline Graphics & 7.55 & $\begin{array}{c}6.6<\mathrm{X} \\
\leq 8.0\end{array}$ & Good \\
\hline $\begin{array}{l}\text { Practicality of } \\
\text { use }\end{array}$ & 23.25 & $\mathrm{X}>20.0$ & $\begin{array}{c}\text { Very } \\
\text { good }\end{array}$ \\
\hline
\end{tabular}

Based on the results of expert validation and teacher's assessment of the borax test practicum instructions using the Ruellia Simplex, Curcuma Longa, Plumeria Rubra, and Portulaca Grandiflora in table 5 , it was concluded that the readability value of $X>12$ was in the very good category, graphical aspects value $6.6<X \leq 8.0$ in good category and practicality of use aspects $X>20.0$ in very good categories.

\section{Conclusion}

The results of this study indicate that the laboratory work instruction of determining borax's content qualitatively for junior high school students could make use of natural indicator drops test of flower the Ruellia simplex, Curcuma longa, Plumeria rubra, and Portulaca grandiflora. Identification using filter paper that has contained natural indicator plant extracts can also be used for borax testing. Based on expert judgment and the teacher's response show that practicum instructions that have been developed is suitable for use
This research is a collaborative research between University of Muhammadiyah Mataram and University of Mataram. This research is fully funded by the Ministry of Research, Technology and Higher Education Republic of Indonesia.

\section{References}

[1] M. Payu, "Analisis Boraks pada Mie Basah yang dijual di Kota Manado," PHARMACON, vol. 3, no. 2, 2014.

[2] M. G. Subiyakto, "Bakso Boraks dan Bleng," Jakarta PT. Gramedia, 1991.

[3] P. A. Fail, R. E. Chapin, C. J. Price, and J. J. Heindel, "General, reproductive, developmental, and endocrine toxicity of boronated compounds," Reprod. Toxicol., vol. 12, pp. 1-8, 1998.

[4] D. Teshima et al., "Clinical management of boric acid ingestion: pharmacokinetic assessment of efficacy of hemodialysis for treatment of acute boric acid poisoning.," $J$. Pharmacobiodyn., vol. 15, pp. 287-294, 1992.

[5] EFSA, "Opinion of the Scientific Panel on Dietetic Products, Nutrition and Allergies on a request from the Commission related to the Tolerable Upper Intake Level of Boron ( Sodium Borate and Boric Acid ) ( Request N 'EFSA-Q-2003-018 )," EFSA J., vol. 80, pp. $1-22,2004$.

[6] K. Jacobi, "Rapid determination of boric acid in borax," J. Am. Chem. Soc., 1904.

[7] S. Siti-Mizura, E. S. Tee, and H. E. Ooi, "Determination of boric acid in foods: Comparative study of three methods," J. Sci. Food Agric., vol. 55, no. 2, pp. 261-268, 1991.

[8] L. M. Zeng, H. Y. Wang, and Y. L. Guo, "Fast Quantitative Analysis of Boric Acid by Gas Chromatography-Mass Spectrometry Coupled with a Simple and Selective Derivatization Reaction Using Triethanolamine," J. Am. Soc. Mass Spectrom., vol. 21, pp. 482-485, 2010.

[9] N. Rahman, "Pengembangan Subjek Specifik Pedagogik (SSP) Praktikum IPA Terpadu SMP/MTS Berbasis Home Materials Terhadap Motivasi Belajar Siswa," J. Elem., vol. 1, no. 1, pp. 1-4, 2018.

[10] A. Hakim, A. Kadarohman, and Y. M. Syah, "Effects of the Natural Product Mini Project Laboratory on the Students Conceptual Understanding.," J. Turkish Sci. Educ., vol. 13, no. 2, pp. 27-36, 2016.

\section{Acknowledgements}


[11] M. D. Gall, W. R. Borg, and J. P. Gall, Educational research: An introduction. Longman Publishing, 1996.

[12] S. Azwar, "Performance test: Function and development of measurement of learning achievement," Yogyakarta: Pustaka Pelajar, 1996.

[13] K. M. Davies, "An introduction to plant pigments in biology and commerce," Plant Pigment. their Manip., vol. 14, pp. 1-22, 2009.

[14] R. Freyre, C. Uzdevenes, L. Gu, and K. H. Quesenberry, "Genetics and Anthocyanin Analysis of Flower Color in Mexican Petunia," J. Am. Soc. Hortic. Sci., vol. 140, no. 1, pp. 45-49, 2015.

[15] K. Torskangerpoll and Ø. M. Andersen, "Colour stability of anthocyanins in aqueous solutions at various $\mathrm{pH}$ values," Food Chem., vol. 89, no. 3, pp. 427-440, 2005.

[16] D. Burdulis, A. Sarkinas, I. Jasutiene, E. Stackeviciene, L. Nikolajevas, and V. Janulis, "Comparative Study of Anthocyanin Composition, Antimicrobial and Antioxidant Activity in Bilberry (Vaccinium Myrtillus L.) and Blueberry (Vaccinium Corymbosum L.) Fruits," Acta Pol. Pharm., vol. 66, no. 4, pp. 399-408, 2009.

[17] J. Lee, R. W. Durst, and R. E. Wrolstad, "Determination of total monomeric anthocyanin pigment content of fruit juices, beverages, natural colorants, and wines by the pH differential method: Collaborative study," J. AOAC Int., vol. 88, no. 5, pp. 1269-1278, 2005.

[18] P. H. Março, R. J. Poppi, I. S. Scarminio, and R. Tauler, "Investigation of the $\mathrm{pH}$ effect and UV radiation on kinetic degradation of anthocyanin mixtures extracted from Hibiscus acetosella," Food Chem., vol. 125, no. 3, pp. 1020-1027, 2011.

[19] O. M. Andersen and K. R. Markham, Flavonoids: chemistry, biochemistry and applications. CRC press, 2005.

[20] A. Gantait, T. Barman, and P. K. Mukherjee, "Validated method for estimation of curcumin in turmeric powder," Indian J. Tradit. Knowl., vol. 10, no. 2, pp. 247-250, 2011.

[21] W. Yj et al., "Stability of curcumin in buffer solutions and characterization of its degradation products . PubMed Commons," J. Pharm. Biomed. Anal., vol. 15, no. 12, pp. 1867-1876, 1997.

[22] D. Strack, T. Vogt, and W. Schliemann,
"Recent advances in betalain research," Phytochemistry, vol. 62, no. 3, pp. 247-269, 2003.

[23] R. R. Leathers, C. Davin, and J. P. Zrÿd, "Betalain producing cell cultures ofBeta vulgaris L. var. bikores monogerm (red beet),"Vitr., vol. 28, no. 2, pp. 39-45, 1992.

[24] G. Trejo-Tapia et al., "Influence of medium constituents on growth and betalain production in cell suspension cultures of Beta vulgaris," Asia-Pacific J. Mol. Biol. Biotechnol., vol. 7, no. 2, pp. 167-172, 1999.

[25] T. Akita, Y. Hina, and T. Nishi, "Production of betacyanins by a cell suspension culture of table beet (Beta vulgaris L.).," Biosci. Biotechnol. Biochem., vol. 64, no. 9, pp. 1807-1812, 2000.

\section{Author Profile}

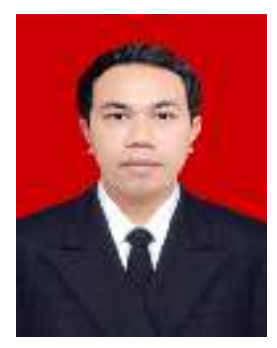

Nanang Rahman, A Lecturer at the Teachers Training and Education Department of the University of Muhammadiyah Mataram, graduated from the University State of Yogyakarta with a concentration in Science Education.. Actively doing research in the field of Science Education. 